\title{
Denitrification and Anaerobic, Nitrate-dependent Acetylene Reduction in Cowpea Rhizobium
}

\author{
By ROBERT M. ZABLOTOWICZ AND DENNIS D. FOCHT \\ Department of Soil and Environmental Sciences, University of California, \\ Riverside, California 92521, U.S.A.
}

(Received 24 October 1978; revised 11 December 1978)

\section{INTRODUCTION}

The dissimilatory reduction of nitrate to nitrous oxide and dinitrogen has recently been discovered in cowpea rhizobia and Rhizobium japonicum (Zablotowicz et al., 1978). The general sequence of denitrification, as proposed by Payne (1973), of $\mathrm{NO}_{3}{ }^{-} \rightarrow \mathrm{NO}_{2}{ }^{-} \rightarrow \mathrm{NO} \rightarrow$ $\mathrm{N}_{2} \mathrm{O} \rightarrow \mathrm{N}_{2}$ is the likely pathway of denitrification in Rhizobium in both free-living and bacteroid forms.

The slower growing, alkali-producing 'cowpea-type' rhizobia probably evolved from tropical soils which remained saturated with water for extended periods of time (Norris, 1964). Nodulation in cowpeas is sensitive to short periods of anoxia (Sallee \& Smith, 1969), and waterlogging depresses nitrogenase activity by decreasing respiratory activity (Sprent, 1971). Ethanol accumulation induced in soybean nodules may be partially responsible for the subsequent disintegration of nodule integrity (Sprent \& Gallacher, 1976).

Minchin \& Pate (1975) found that, under waterlogging conditions, peas (Pisum sativum) exhibited extreme degradation of nodule tissue in $14 \mathrm{~d}$, while functional bacteroids in cowpeas (Vigna) could be observed after $32 \mathrm{~d}$. Though better $\mathrm{O}_{2}$ transport in cowpeas might be a possible explanation for the differences, as suggested by Minchin \& Pate (1975), the possession of a dissimilatory nitrate reductase in the cowpea rhizobia cannot be precluded. Such an enzyme has been found in suspensions of $R$. japonicum bacteroids, though an active dissimilatory nitrite reductase was not detected (Daniel \& Appleby, 1972). Rhizobium japonicum can use nitrate as an alternative electron acceptor to oxygen to generate ATP for nitrogenase activity, and nitrogenase and nitrate reductase activities remain constant until nitrite accumulates and inhibits nitrogenase activity (Rigaud et al., 1973).

\section{METHODS}

Preparation of bacteroids. California no. 5 blackeyes (Vigna unguiculata L. Walp.) were grown in sand culture in the greenhouse. Plants were irrigated with half-strength $\left(12.5 \mu \mathrm{g} \mathrm{N} \mathrm{ml}^{-1}\right)$ Summerfield solution (Summerfield et al., 1977). The nutrient solution (50 l) was continuously recycled throughout the experiment with no further addition of mineral salts. The plants were inoculated just after seedling emergence with $10 \mathrm{ml}$ of a $5 \mathrm{~d}$ culture of strain 176A32 (obtained from J. C. Burton, Nitragin Co., Milwaukee, Wis., U.S.A.) grown on yeast extract/mannitol broth.

The plants were harvested at noon $40 \mathrm{~d}$ after emergence. The roots were surface-sterilized by immersion in $70 \%(\mathrm{v} / \mathrm{v})$ ethanol. The nodules were removed, rinsed twice in $70 \%(\mathrm{v} / \mathrm{v})$ ethanol, then three times in sterile distilled water. They were disrupted under $\mathrm{He}$ with a Waring blender in $0.01 \mathrm{M}-\mathrm{KH}_{2} \mathrm{PO}_{4} / 0.01 \mathrm{M}$-sodium ascorbate buffer, $\mathrm{pH} 7 \cdot 2$, filtered through sterile cheesecloth to remove the coarser tissue particles, and the filtrate was centrifuged for $10 \mathrm{~min}$ at $164 \mathrm{~g}$. The supernatant was decanted and centrifuged for $10 \mathrm{~min}$ at $12100 \mathrm{~g}$; the resulting pellet, containing the bacteroid fraction, was suspended in phosphate buffer to give $12 \cdot 8 \mathrm{mg}$ dry wt cells $\mathrm{ml}^{-1}$ and was stored under a He atmosphere.

Incubation. Erlenmeyer flasks $(50 \mathrm{ml}$ ), containing $10 \mathrm{ml} \mathrm{CS7} \mathrm{medium} \mathrm{(Pagan} \mathrm{et} \mathrm{al.,} \mathrm{1975)} \mathrm{with} 30 \mathrm{mM}-$ glucose instead of arabinose, were used to assay acetylene reduction. One set of flasks contained $4 \mathrm{~mm}$ - 


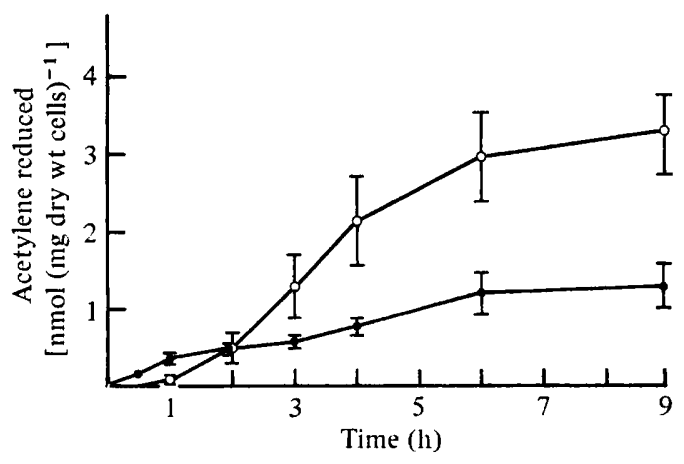

Fig. 1

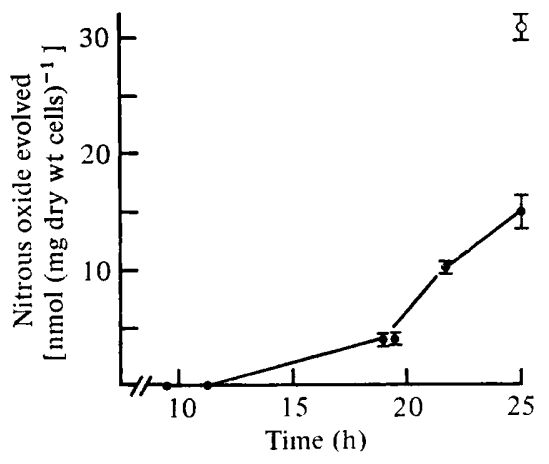

Fig. 2

Fig. 1. Nitrogenase activity, as measured by acetylene reduction, in cowpea bacteroid preparations incubated in a $\mathrm{He}$ atmosphere in the presence of nitrate $(O)$ or in its absence (O). The results show the mean values from three experiments; bars show the standard deviation.

Fig. 2. Nitrous oxide evolution by cowpea bacteroid preparations incubated in a He atmosphere in the presence of nitrate $(\Theta)$, and nitrous oxide evolved after addition of trichloroacetic acid $(O)$. The results show the mean values from three experiments; bars show the standard deviation.

$\mathrm{K}^{15} \mathrm{NO}_{3}$ (enriched with $99.3 \%{ }^{15} \mathrm{~N}$ ) while the other set (control) contained no nitrate. All flasks were autoclaved at $121{ }^{\circ} \mathrm{C}$ for $5 \mathrm{~min}$. The sterile flasks were sealed with a sterile serum stopper and flushed four times with $\mathrm{He}$ at $1.26 \times 10^{5} \mathrm{~Pa}(1.25 \mathrm{~atm})$; they were then injected with acetylene to give $6.5 \times 10^{3} \mathrm{~Pa}(0.06 \mathrm{~atm})$ and $5.0 \mathrm{ml}$ of the bacteroid preparation were added by syringe. The flasks were placed in a rotary shaker $\left(100 \mathrm{rev} . \mathrm{min}^{-1}\right)$ water bath at $30^{\circ} \mathrm{C}$.

Gas samples $(0.05 \mathrm{ml})$ were removed periodically up to $9 \mathrm{~h}$ for acetylene reduction assay and $1.0 \mathrm{ml}$ samples were removed for $\mathrm{N}_{2} \mathrm{O}$ analyses between 9 and $25 \mathrm{~h}$. The experiments were terminated after $25 \mathrm{~h}$ by adding $5.0 \mathrm{ml} 1 \mathrm{M}$-trichloroacetic acid.

Analytical methods. Ethylene concentrations were determined using a Varian 3700 gas chromatograph with a flame ionization detector and a $2 \mathrm{~m} \times 1.6 \mathrm{~mm}$ column packed with 80 to 100 mesh Poropak $\mathrm{N}$, using $\mathrm{He}$ as a carrier gas. Nitrous oxide was determined using the same instrument fitted with a thermal conductivity detector and a Poropak $Q$ column $(5.5 \mathrm{~m} \times 1.6 \mathrm{~mm})$.

A Finnigan $3100 \mathrm{C}$ mass spectrometer interfaced with a gas chromatograph was used for isotopic analysis of nitrous oxide and dinitrogen according to Focht (1978).

Nitrate and nitrite were determined in a Technicon Autoanalyzer II using the cadmium reduction method of Strickland \& Parsons (1965).

\section{RESULTS}

Although nitrate gave an immediate decrease in acetylene reduction in bacteroids, activity steadily increased thereafter (Fig. 1).

Nitrous oxide was first detected at $19 \mathrm{~h}$ in the nitrate-enriched treatments of bacteroids. It continued to accumulate until the end of the experiment (Fig. 2). No nitrous oxide was detected at any time in any of the control flasks. Nitrous oxide increased from $15 \cdot 1$ to $31 \mathrm{nmol}$ (mg dry wt cells) ${ }^{-1}$ when trichloroacetic acid was added to the incubation mixture. This may have been due to disruption of cell membranes and release of 'trapped' nitrous oxide inasmuch as nitrous oxide reductase is membrane-bound (Payne, 1973). The nitrate concentration decreased from $39 \cdot 2 \mu \mathrm{mol}$ per flask at the beginning of the experiment to $19 \cdot 0 \mu \mathrm{mol}$ per flask at the end. Subsequent accumulation of nitrite (less than $0.1 \mu \mathrm{mol}$ nitrite detected) did not occur. No ${ }^{15} \mathrm{~N}_{2}$ was detected at the end of the experiment and $98.0 \pm 1.0 \%$ of the $\mathrm{N}_{2} \mathrm{O}$ was of mass 46 (theoretical value $98.6 \%$ ). 


\section{DISCUSSION}

We have observed that the anaerobic reduction of acetylene to ethylene in bacteroids was increased by nitrate, which agrees with the results of Rigaud et al. (1973) who showed that the dissimilatory reduction of nitrate can support nitrogen fixation in soybean bacteroids. There are, however, three noticeable differences between the two studies. Firstly, we did not observe an immediate reduction of acetylene which may have been due to the induction of the nitrogenous oxide reductases. Secondly, we observed a longer maintenance of acetylene reduction activity, probably because of further reduction of nitrite. Thirdly, Rigaud et al. (1973) found an accumulation of nitrite to which they attributed the subsequent cessation of acetylene reduction activity, while we found no accumulation of nitrite.

We have demonstrated that the denitrifying enzyme system, excepting nitrous oxide reductase, is functional in cowpea bacteroids by noting that both atoms of $\mathrm{N}_{2} \mathrm{O}$ came from ${ }^{15} \mathrm{NO}_{3}{ }^{-}$. Failure to observe labelled $\mathrm{N}_{2}$ during the incubation is most likely due to the inhibition of nitrous oxide reduction since concentrations of acetylene as low as $0.1 \%(\mathrm{v} / \mathrm{v})$ reversibly block nitrous oxide reductase (Balderson et al., 1976; Yoshinari \& Knowles, 1976). Thus, our results do not preclude the existence of a functional nitrous oxide reductase in bacteroids.

Possession of a denitrification and a nitrogen-fixing pathway in the same organism may appear wasteful in terms of plant nitrogen usage, but, besides helping organisms to survive anaerobic conditions, it might be important to Rhizobium-legume symbiosis by maintaining nodule integrity during anoxic conditions in the soil medium. Minchin \& Summerfield (1976) described characteristics to be used in a breeding programme for cowpeas to maintain nodule integrity. The presence of a full nitrogen oxide reductase system may be an important criterion in the selection of Rhizobium for many irrigated and rain-fed tropical legumes.

This work was supported in part by the Agency for International Development, grant no. AIDTA-G-1141, and the National Science Foundation RANN, grant no. G134733X. We wish to thank Peter Clark for his assistance with the mass spectrometer.

\section{REFERENCES}

Balderson, W. L., Shear, B. \& Payne, W. J. (1976). Blockage of nitrous oxide reduction in Pseudomonas perfectomarinus. Applied and Environmental Microbiology 31, 504-508.

DANiel, R. M. \& Appleby, C. A. (1972). Anaerobicnitrate, symbiotic, and aerobic growth of Rhizobium japonicum. Effects of cytochrome P-450, other haemoproteins, nitrate and nitrite reductases. Biochimica et biophysica acta 275, 347-354.

Focht, D. D. (1978). Methods for analysis of denitrification in soils. In Nitrogen in the Environment, vol. 2, pp. 433-490. Edited by D. R. Nielson \& J. G. MacDonald. New York: Academic Press.

Minchin, F. R. \& Pate, J.S. (1975). Effects of water, aeration and salt regime on nitrogen fixation in a nodulated legume - definition of an optimum root environment. Journal of Experimental Botany 26, 60-69.

Minchin, F. R. \& Summerfield, R. J. (1976). Symbiotic nitrogen fixation and vegetative growth of cowpea (Vigna unguiculata) in waterlogged conditions. Plant and Soil 22, 113-127.

NorRIS, D. O. (1964). Acid production in Rhizobium: a unifying concept. Plant and Soil 22, 143-166.

Pagan, J. D., Child, J. J., Scowcroft, W. R. \&
Gibson, A. H. (1975). Nitrogen fixation by Rhizobium cultured on a defined medium. Nature, London 256, 406-408.

Payne, W. (1973). Reduction of nitrogenous oxides by microorganisms. Bacteriological Reviews 37, $407-452$.

Rigaud, J. F., Bergersen, F. J., Turner, G. L. \& DANIEL, R. M. (1973). Nitrate dependent anaerobic acetylene-reduction and nitrogen-fixation by soybean bacteroids. Journal of General Microbiology 77, 137-144.

Sallee, W. R. \& Smith, F. L. (1969). Commercial blackeye bean production in California. California Agricultural Experiment Station Bulletin 549.

SPRENT, J. I. (1971). The effects of water stress on nitrogen-fixing root nodules. I. Effects on the physiology of detached soybean nodules. New Phytologist 70, 9-17.

Sprent, J. I. \& Gallacher, A. (1976). Anaerobiosis in soybean water nodules under water stress. Soil Biology and Biochemistry 8, 317-320.

Strickland, J. D. H. \& Parsons, T. R. (1965). Determination of reactive nitrate. In Manual of Seawater Analysis, 2nd edn, Fisheries Research Board of Canada, Bulletin no. 125. 
Summerfield, R. J., Huxley, P. A. \& Minchin, F. R. (1977). Plant husbandry techniques for growing legumes under simulated tropical conditions in controlled environments. Experimental Agriculture 13, 81-92.

YoshinaRI, T. \& Knowles, R. (1976). Acetylene inhibition of nitrous oxide reduction by denitrifying bacteria. Biochemical and Biophysical Research Communications 69, 705-710.

Zablotowicz, R. M., Eskew, D. L. \& Focht, D. D. (1978). Denitrification in Rhizobium. Canadian Journal of Microbiology 24, 757-760. 